\title{
Assessment of Genetic Diversity for Storage Seed Protein in a Set of Released Varieties and their Diallel Set of Crosses in Indian Mustard [Brassica juncea (L.) Czern. \& Coss.] Using SDS PAGE
}

\author{
Kuldeep Jangid*, K. Ram Krishna, Naresh Parashar, Bhawana Bhatt, \\ Arpit Gaur and Vinod Kumar
}

Department of Plant Breeding and Genetics, S.K.N. College of Agriculture, Jobner

Sri Karan Narendra Agriculture University, Jobner, Jaipur - 303329, Rajasthan, India

*Corresponding author

\begin{tabular}{|c|c|}
\hline & A B S T R A C T \\
\hline Keywords & \multirow{4}{*}{$\begin{array}{l}\text { Brassica species are major oilseed crops which are an increasingly important part of } \\
\text { the human diet worldwide. In present investigation } 11 \text { varieties and their } 55 \mathrm{~F}_{1} \text { 's were } \\
\text { characterized for storage seed protein profiling using sodium dodecyl sulphate - } \\
\text { polyacryl amide gel electrophoresis (SDS - PAGE). The electrophoresis of the } \\
\text { proteins revealed protein bands in the range of } 80 \mathrm{kD} \text { to less than } 14 \mathrm{kD} \text { molecular } \\
\text { weight (MW). Out of } 15 \text { bands } 14 \text { bands were more or less monomorphic and only } \\
\text { single band was polymorphic. Gels were scored for the presence }(1) \text { and absence }(0) \\
\text { for polymorphic band. The similarity coefficient among these genotypes ranged from } \\
1 \text { to } 0.25 \text {. A large number of pairs assumed value of } 1.0(61.6 \%) \text { followed by } 0.8 \\
(35.4 \%) \text { about } 3 \% \text { cases showed similarity coefficient of less than } 0.8 \text {. }\end{array}$} \\
\hline $\begin{array}{l}\text { Brassica, SDS- } \\
\text { PAGE, Cluster } \\
\text { analysis, } \\
\text { UPGMA. }\end{array}$ & \\
\hline Article Info & \\
\hline $\begin{array}{l}\text { Accepted: } \\
\text { 21 June } 2017 \\
\text { Available Online: } \\
10 \text { August } 2017\end{array}$ & \\
\hline
\end{tabular}

\section{Introduction}

Brassica species are major oilseed crops as well as vegetable crops like broccoli, cabbages, Chinese cabbage including leaf mustard which is an increasingly important part of the human diet worldwide. Among Brassica species, mustard (Brassica juncea L.) displays a great polymorphism and is a source of different types of vegetables, condiment and oilseeds. Mustard belongs to family Crucifereae (Syn. Brassicacae). It is natural amphidiploid having chromosome no $(2 n=36)$. It is self-pollinated but certain amount of cross-pollination (2-15\%) occurs due to insects and other factors. The place of origin of mustard is China and from there it was introduced to India (Prain, 1898 and Bailey, 1922.).

At present time, mustard has been identified as a good crop for supporting bee keeping activity. The oil of mustard possesses a sizable amount of erucic acid (38-57\%), together with linolenic acid (4.7 to13.0\%). The oleic and linoleic acids, which have a higher nutritive value, together constitute about $27 \%$. The protein content in rapeseed and mustard normally ranges between 24$30 \%$ on the basis of whole seed basis and between $35-40 \%$ on meal basis. But the presence of toxic glucosinolates in the 
mustard cake renders it unsuitable as a source of human protein.

In general, genetic improvement of crops can be accelerated when there is a broad genetic diversity and information on these genetic resources are available. The collection of these genetic resources and the assessment of genetic diversity within and between these resources should be given priority for varietal improvement. At the same time it is necessary to develop better methods of characterization and evaluation of germplasm collections, to improve strategies for conservation and collection of germplasm and to increase the utilization of plant genetic resources. In a common practice, genetic improvement is easy in those species/crops, which have broad genetic diversity, and the information regarding these hidden genetic resources is easily available. The electrophoretic profile of seed storage protein is a method to investigate genetic variation and to classify plant varieties (Isumera et al., 2001). Seed protein is not sensitive to environmental fluctuations, its banding pattern is very stable and has been advocated for taxonomic study of various species (Vaughan and Denford, 1968; Yadava et al., 1979 and Akhtar, 2001) and cultivars identification purpose. It has been widely suggested that such banding patterns could be important supplemental method for cultivar identification, particularly when there are legal disputes over the identity of a cultivar or when cultivars are to be patented (Tanskley and Jones, 1981).

Seed storage protein is useful tool for studying genetic diversity of wild and cultivated rice (Thanh and Hirata, 2002). However, the information on the SDS-PAGE on different species of Brassica for genetic diversity is still limited (Mukhlesure and Hirata, 2004). The objective of the present study is to check the variation in storage protein with the help of SDS-PAGE. Analysis of SDS-PAGE is simple and relatively less expensive, which are of added advantages for use in practical plant breeding.

\section{Materials and Methods}

\section{Plant materials}

A total of 11 varieties and their $55 \mathrm{~F}_{1}$ 's of mustard (Brassica juncea) were evaluated in the present study. Experimental material was obtained from AICRP on oilseed (Taramira) Division, Department of Plant Breeding and Genetics, S.K.N. COA., Jobner.

\section{Protein extraction and gel electrophoresis}

For the extraction of proteins, the $100 \mathrm{mg}$. of seed coat removed samples were ground using pestle and mortar. The seed powder of each variety was taken in an Eppendorf tube and $1 \mathrm{ml}$. of defatting solution (Chloroform, methanol and acetone in 2:1:1 ratio) was then poured in each tube. After thorough shaking, the Eppendorf tubes were left for $3 \mathrm{hr}$. The supernatant was decanted and samples were then kept for some times for drying. Then after, $1 \mathrm{ml}$. of extraction buffer $(0.0625 \mathrm{M}$ Tris$\mathrm{HCl}$ at $\mathrm{p}^{\mathrm{H}} 6.8,8 \mathrm{M}$ Urea, 2\% SDS, 5\% 2Mercaptoethanol) was added and Eppendorf tubes were kept overnight at $10^{\circ} \mathrm{C}$. The next day, the samples were centrifuged at 10,000 rpm for $20 \mathrm{~min}$. Supernatant $(10 \mu \mathrm{L}$.) was used for protein separation. SDS-PAGE was conducted according to the procedure of Laemmli (1970) with minor modifications described by Mukhlesure and Hirata (2004). $10 \mu 1$ of these samples were loaded into the wells of the polyacrylamide gel slab prepared for electrophoresis. The electrophoresis was carried out on BioRAD vertical gel electrophoresis equipment (Model: Protean II $\mathrm{Xi}$ Cell) along with its cooling unit with a power supply maintained at $20 \mathrm{~mA}$ for four and half hours. Two separate gels were run under similar electrophoretic conditions in 
order to check the reproducibility of the results. After electrophoresis gels were stained with Coomassie brilliant blue R 250 overnight; followed by distaining overnight and finally washing in tap water.

\section{Data analysis}

Gels were scored for the presence (1) and absence (0) of every protein band. These binary data were analyzed using NTSYS-pc (Numerical Taxonomy System, Version 2.1, Rohlf 2000). The SIMQUAL sub-programme was used to calculate the Jaccard's coefficient using following formula (Jaccard, 1908).

Jaccard's coefficient $=\mathrm{N}_{\mathrm{AB}} /\left(\mathrm{N}_{\mathrm{AB}}+\mathrm{N}_{\mathrm{A}}+\mathrm{N}_{\mathrm{B}}\right)$

Where, $\mathrm{N}_{\mathrm{A}}$ and $\mathrm{N}_{\mathrm{B}}$ represents no. of bands in sample $A$ and sample $B$, respectively. $N_{A B}$ is the number of bands shared in the samples. Similarity matrices as computed by the programme were used to construct the UPGMA (un-weighted pair group method with arithmetic average dendrograms to elucidate the diversity among the genotypes studied. Statistical stability of the branches in the cluster was estimated by bootstrap analysis with 1000 replicates, using Winboot software programme (Yap and Nelson, 1996).

\section{Results and Discussion}

The present investigation was carried out to distinguish between 11 parents and their 55 diallel crosses of Indian mustard (Brassica juncea L.) on the basis of storage seed protein profile using SDS-PAGE. The parents / genotypes used in the study were different released varieties, therefore, it was thought justified to determine their differences among themselves on the basis of the profile of their seed storage proteins. Characterization of genotypes based on seed storage protein/subunits is well documented in different groups of crops such as blackgram
(Ghafoor and Ahmad, 2005; Ghafoor et al., 2002), Capsicum annuum L. (Anu and Peter, 2003), Solanum (Menella et al., 1999), Vignaspp (Rao et al., 1992; Sharma, 2012; Chaoudhary, 2013) and Wheat (Siddiqui and Naz, 2009), including mustard (Rabbani et al., 2001; Geetha and Balamurugan, 2011; Mukhlesure and Hirata, 2004; Parashar, 2014).

Sodium Dodecyl Sulphate-Polyacrylamide Gel Electrophoresis (SDS-PAGE) as described by Laemmeli (1970) is a powerful and dependable technique for characterization of proteins. In present investigation, the total acid soluble proteins (Tris-HCL soluble) were extracted from cotyledons of the seeds following the procedure of Mukhlesure and Hirata (2004). Four different aliquots of proteins extract were examined for loading on the gel. It was found that loading of 10 $\mathrm{uL}$ of protein extract produced more sharper bands as compared to 5,20 or $30 \mathrm{uL}$ of sample aliquots, therefore in all other experiments, $10 \mathrm{uL}$ of protein extract was loaded during electrophoresis (fig-1).

The protein extracts from the cotyledons of the seeds of mustard genotypes were prepared and 14 samples loaded on a gel plate along with marker protein. The comb used in these experiments could develop 15 wells for loading the samples. The electrophoregram of the gel revealing banding pattern of the mustard genotypes is shown in figures-2.

It may be seen that the protein bands represented a Mol. Wt. of $80 \mathrm{kD}$ to less than $14 \mathrm{kD}$. Further these appeared to represent four different regions. In the same figure alphabetic designations have been assigned to different protein bands. A perusal of protein subunits bands through Figure-2 revealed that four different recognizable regions of protein profiles were resolved. Parashar (2014) has also described a similar picture while 
studying SDS-PAGE of storage seed proteins of 45 different genotypes of mustard. Further, similar studies performed by Rabbani et al., (2001) and Turi et al., (2010) have also demonstrated 4 regions or darkly stained regions of protein bands.

A perusal of protein subunit bands of 11 parent genotypes and their 55 reciprocal crosses revealed that there were 15 well recognizable protein bands. However when compared, the $\mathrm{A}$ to $\mathrm{N}$ protein bands were more or less similar (monomorphic) whereas only " $O$ " 'band showed polymorphism. On contrary, Parashar (2014) in his studies on 45 mustard genotypes, (which includes the parents of present study also) observed that out of 15 bands observed, 7 were polymorphic. Depending on the intensity of stain in the band, the binary data was generated where value of ' 1 ' was assigned to presence of darker stained protein band and value of ' 0 ' assigned to the presence of protein band with very light stain. The genotype 20 (a cross between Bio-902 x RH819) was distinct from the rest of 65 genotypes as it scored ' 0 ' values (being less stained) for all the protein bands. The presence or absence of band was used to generate binary data for each of the 66 genotypes. Using these binary data and NTSYSpc software, the Jaccard's similarity coefficients were obtained. The similarity coefficient assumed only values of $0.25,0.31$, $0.8 \quad$ and 1.00 .

Table.1 Pedigree of the genotypes used in the study

\begin{tabular}{|c|c|c|c|}
\hline Sr.No. & Genotype & Pedigree & Source/Origin \\
\hline $\begin{array}{l}1 . \\
2 .\end{array}$ & $\begin{array}{l}\text { RB-50 } \\
\text { PBR-97 }\end{array}$ & $\begin{array}{c}\text { LAXMI x RH } 9617 \\
(\text { DIR } 202 \times \text { PR } 34 \times \\
\text { V3) } x(\text { RLM } 619 x \\
\text { VARUNA) }\end{array}$ & $\begin{array}{l}\text { CCS HAU Bawal } \\
\text { PAU RS Bathinda, } \\
\text { Punjab }\end{array}$ \\
\hline $\begin{array}{l}3 . \\
4 .\end{array}$ & $\begin{array}{l}\text { RH-819 } \\
\text { ROHINI }\end{array}$ & $\begin{array}{c}\text { Selection from } \\
\text { natural population } \\
\text { of VARUNA }\end{array}$ & $\begin{array}{c}\text { CCS HAU Hisar } \\
\text { CSAUT Kanpur (UP) }\end{array}$ \\
\hline 5. & BIO-902 & $\begin{array}{c}\text { Somaclonal variation } \\
\text { of } \\
\text { VARUNA (1993) }\end{array}$ & IARI, New Delhi \\
\hline 6. & NRCDR-2 & $\begin{array}{l}\text { MDOC-43 x } \\
\text { NBPGR-36 }\end{array}$ & DRMR, Bharatpur \\
\hline 7. & RGN-73 & RGN 8 x PUSA BOLD & RAU, Sriganganagar \\
\hline 8. & GEETA & $\begin{array}{c}\text { Spontaneous mutant of } \\
\text { cultivar RH-30 }\end{array}$ & CCS HAU Hisar \\
\hline 9. & NPJ-112 & $\begin{array}{c}\text { SEJ-8 x PUSA } \\
\text { JAGNNATH }\end{array}$ & IARI, New Delhi \\
\hline 10. & KRANTI & $\begin{array}{l}\text { selection from } \\
\text { VARUNA }\end{array}$ & $\begin{array}{l}\text { GBPUA\&T, } \\
\text { Pantnagar }\end{array}$ \\
\hline 11. & LAXMI & $\begin{array}{c}\text { PR-15 (KRANTI) } x \\
\text { RH-30 }\end{array}$ & CCSHAU Hisar \\
\hline
\end{tabular}


Fig.1 A close-up view of electrophoregram showing the resolution of protein subunit bands in loading of different aliquots of samples

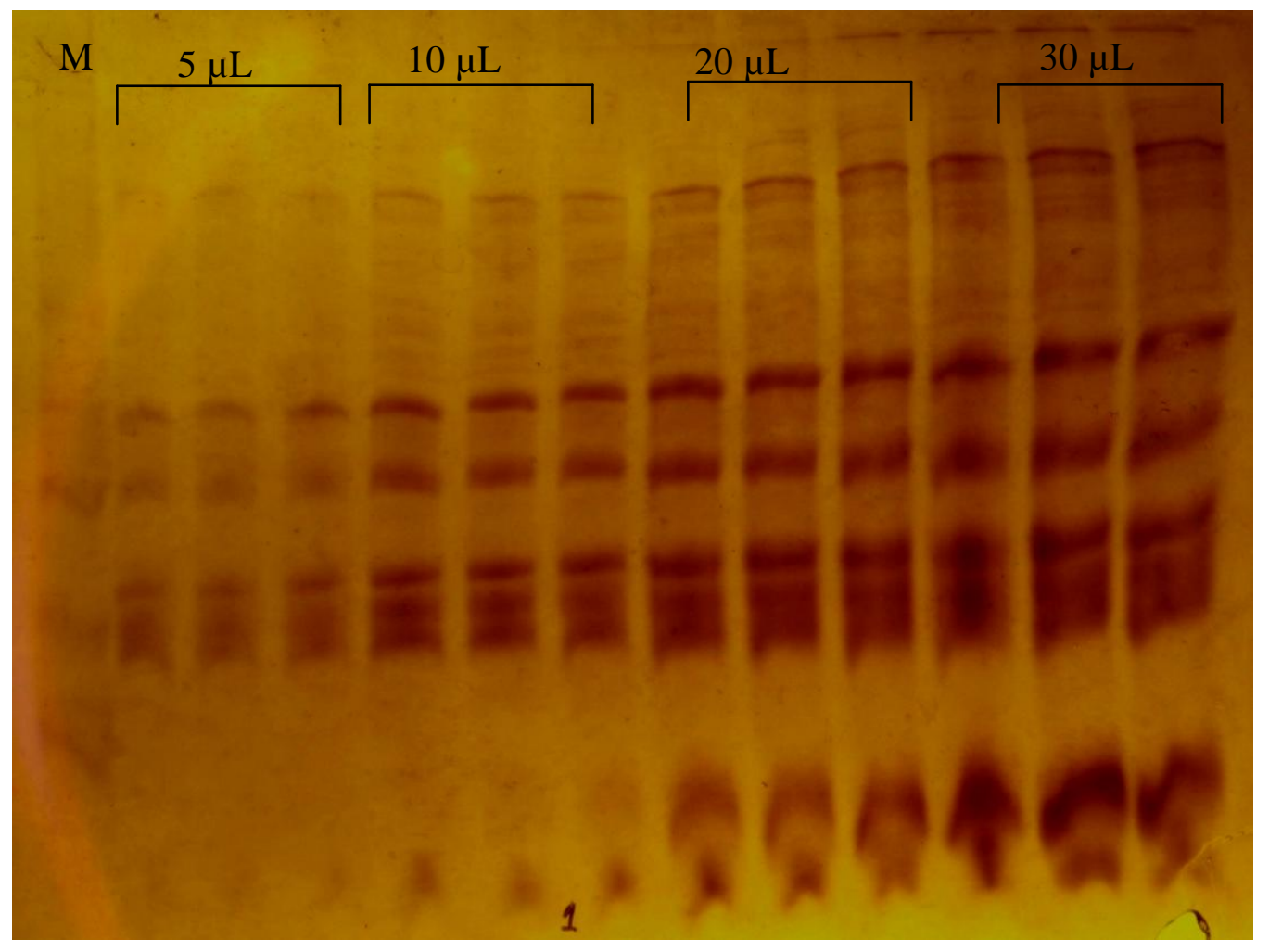

Fig.2 A close up view of electrophoregram of mustard genotypes

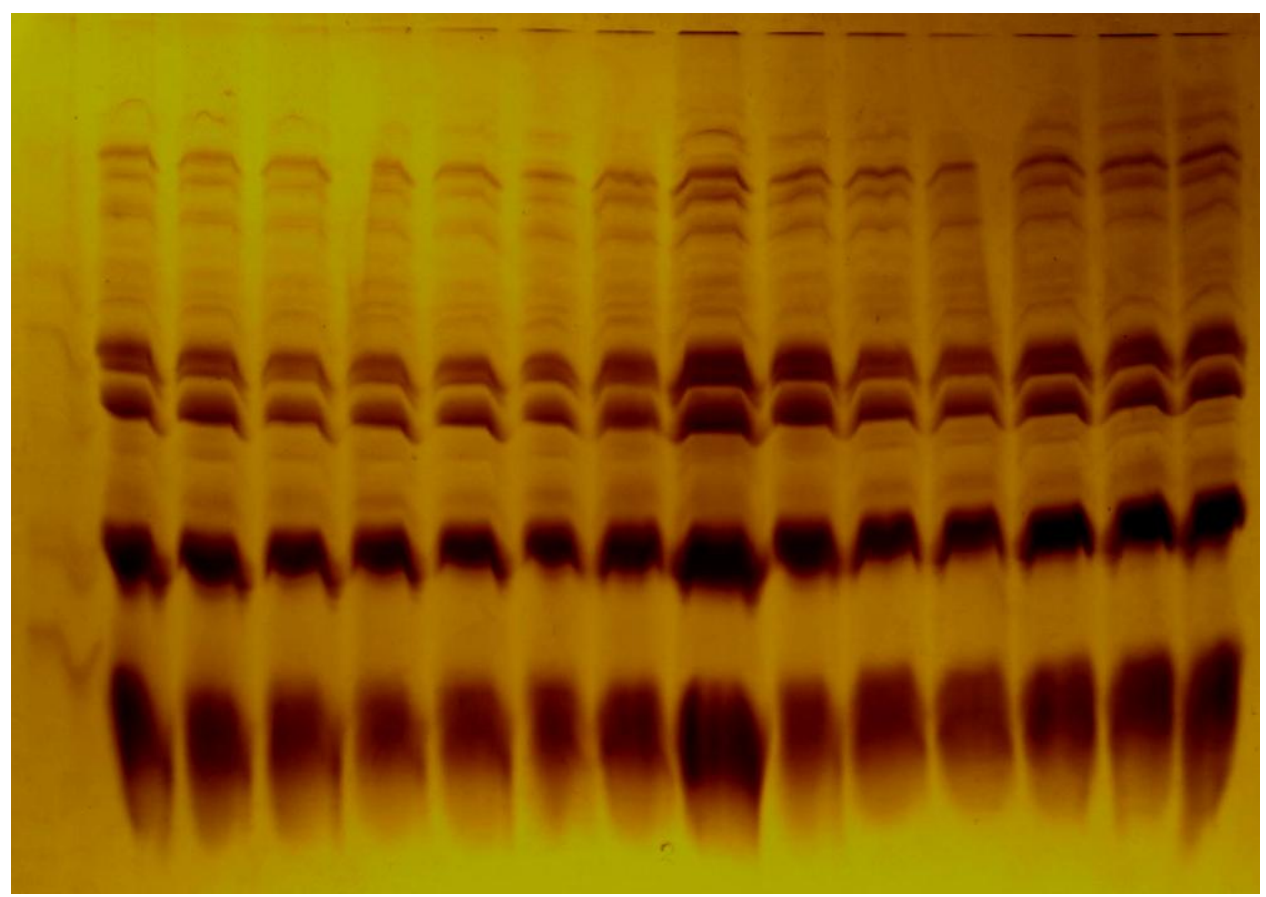


Fig.3 Dendrogram of 66 genotypes of mustard revealed by UPGMA cluster analysis of SDSPAGE based genetic similarity estimates

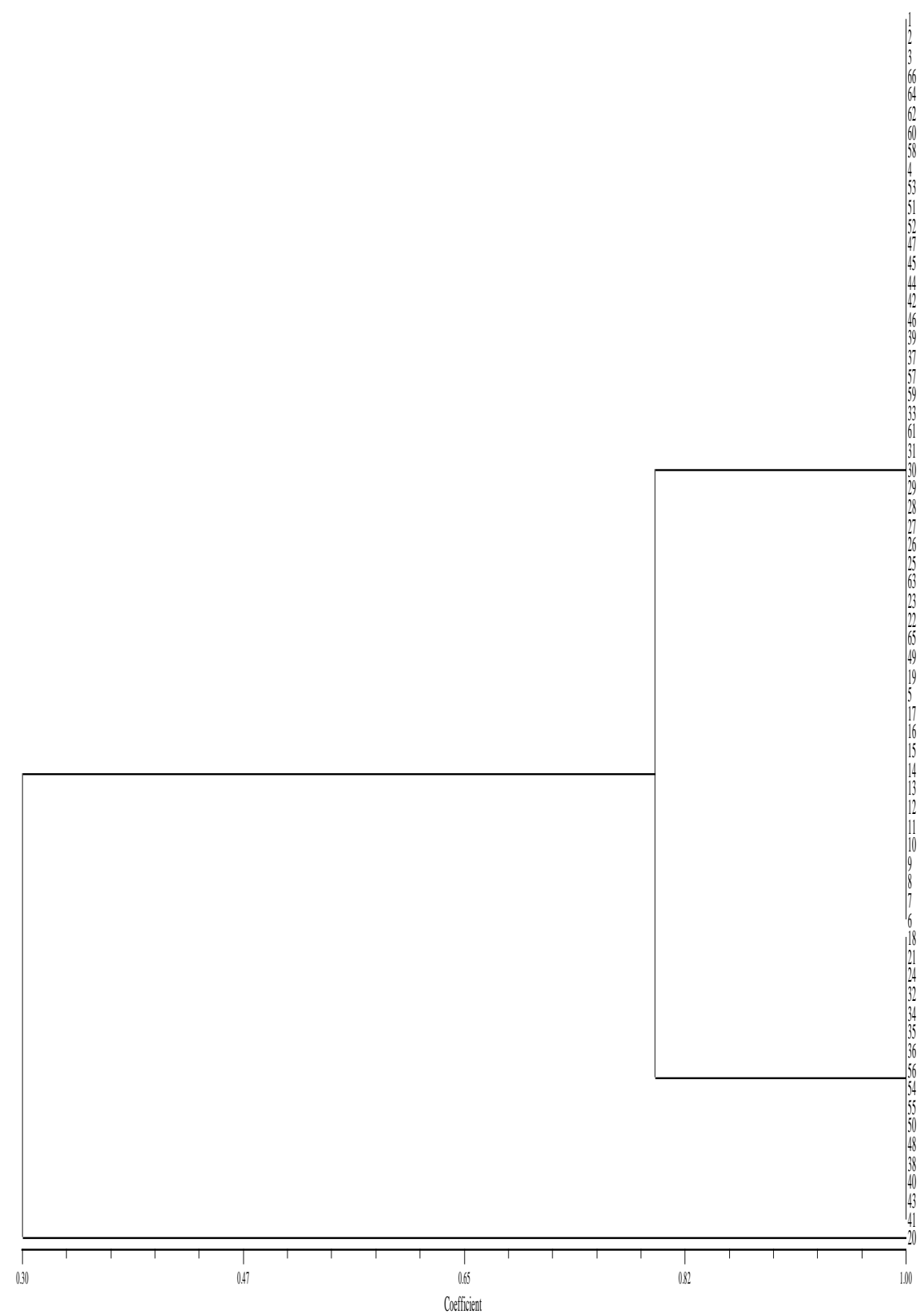

Higher coefficient of values was associated with large number of pairs. A perusal of similarity coefficient revealed that a large number of pairs assumed value of $1.0(61.6$ $\%)$ followed by $0.8(35.4 \%)$ about $3 \%$ cases showed similarity coefficient of less than 0.8 . Thus it may be inferred that large number of genotypes are closely similar, at least on the basis of seed storage protein profile. A dendrogram was constructed using Jaccard's similarity coefficients obtained for protein band binary data observed on 66 genotypes of mustard employing NTSYSpc program (Fig. 3 ). The cluster analysis of the genotypes revealed 3 distinct clusters at more than $75 \%$ similarity coefficient of the 3 branching observed, genotype 20 (Bio-902 x RH-819) was quite distinct from rest of the two clusters. It is interesting to note that all the parents fell in cluster 1 along with most of 
their F1 crosses (38 crosses) whereas rest of the 16 crosses fell in cluster 2. Although, Parashar (2014) observed 5 clusters but only at above $80 \%$ similarity coefficient indicating that the clusters are genetically relatively close to each other. The observations of the present study may seek support from the origin of the parents. A perusal of the pedigree of the parents involved in the present study indicated that an old ruling variety of Indian mustard "Varuna" was involved at one or the other stage of their development (Table 1). This may be a plausible reason why the parents of the present study are indistinguishable on the basis of SDS-PAGE of storage seed protein profile. Rabbani et al., (2001) also failed to distinguish 52 accession on the basis of storage seed protein profile and based on this arrived on the same conclusion.

\section{Acknowledgement}

The authors are thankful to the Dean, College of Agriculture, Sri Karan Narendra Agriculture University, Jobner- Jaipur for providing necessary facilities and permission to conduct the study.

\section{References}

Anu, A. and Peter, K.V. 2003. Analysis of seed protein of 29 lines of Capsicum annuum L. by polyacrylamide gel electrophoresis. Genet. Res. Crop Evol., 50: 239-243.

Choudhary, M. 2013. Electrophoretic characterization of cowpea (Vigna unguiculata L. Walp.) mutants for storage seed protein profile. In: M.Sc. (Ag.) Thesis submitted to S.K.R.A.U. Bikaner and Campus-Jobner.

Geetha, V.V. and Balamurugan, P. 2011. SDS-PAGE electrophoresis in mustard cultivars. Int. J. Agric. Res., 6(5): 437443.
Ghafoor, A. and Ahmad, Z. 2005. Diversity of agronomic traits and total seed protein in Black gram Vigna mungo (L.) Hepper. Acta Biol Cracoviensia Ser Bot., 47(2): 69-75.

Ghafoor, A., Ahmad, Z., Qureshi, A.S. and Bashir, M. 2002. Genetic relationship of Vigna mungo (L.) Hepper and $V$. radiata (L.) $R$. Wilezek based on morphological traits and SDS-PAGE. Euphytica, 123: 367-378.

Isumera, T., Noda, C., Mori, S., Yamashita, M., Nakanishi, H., Inoue, M. and Kamijima, O. 2001. Genetic variation and geographical distribution of Azuki bean (Vigna angularis) landraces based on the electrophoregram of seed storage proteins. Breed Sci., 5: 225-230.

Jaccard, P. 1908. Nouvelles recherches sur la distribution florale. Bull Soc. Vaud Sci. Nat., 44: 223-270.

Laemmli, U.K. 1970. Cleavage of structural proteins during the assembly of the head of bacteriophage T4. Nature, 227: 680685.

Menella, G., Sanaja, V.O., Tonini, A. and Magnifico, V. 1999. Seed storage protein characterization of Solanum sps. and of cultivars and androgenetic lines of $S$. melogena L. by SDS-PAGE and AE-HPLC. Seed Sci. Technol., 27: 2335.

Mukhlesure, R.M. and Hirata, Y. 2004. Genetic diversity in brassica species using SDS-PAGE analysis. J. Biol. Sci., 4(2): 234-238.

Parashar, N. 2014. Genetic diversity for storage seed protein profile in mustard (Brassica juncea (L.) Czern. \& Coss.) genotypes. In: M.Sc. (Ag.) Thesis, SKNRAU Jobner.

Rabbani, M.A., Qureshi, A.A., Afzal, M., Anwar, R. and Komatsu, S. 2001. Characterization of mustard (Brassica juncea (L.) Czern. \& Coss.) germplasm by SDS-PAGE of total seed proteins. 
Pak. J. Bot., 33(2): 173-179.

Rao, R., Vagliol, M.D., D'Urzo, M.P. and Month, L. 1992. Identification of Vigna spp. through specific seed storage polypeptides. Euphytica, 62: 39-43.

Rohlf, F.J. 2000. NTSYS-pc: Numerical Taxonomy System. Ver. 2.1. Exeter Software, Setauket, NY, USA. 29-34.

Sharma, D.B. 2012. Genetic diversity in cowpea (Vigna unguiculata L. Walp.) using protein profile. In: M.Sc. (Ag.) Thesis submitted to S.K.R.A.U., Bikaner and Campus-Jobner.

Siddiqui, M.F. and Naz, N. 2009. Protein landmarks for diversity assessment in wheat genotypes. Afr. J. Biotech., 8(9): 1855-1859.

Tanksley, S.D. and Jones, R.A. 1981. Application of alcohol dehydrogenase allozymes in testing the genetic purity of F1 hybrids of tomato. Hort, Sci., 16: 179-181.

Thanh, V.O.C. and Hirata, Y. 2002. Seed storage protein diversity of three rice species in the Mekong Delta. Biosphere Conser., 4: 59-67.

Vaughan, J.G. and Denford, K.E. 1968. An acrylamide gel electrophoretic study of the seed proteins of Brassica and Sinapis species, with special reference to their taxonomic value. J. Exp. Bot., 19: 724-732.

Yap, I.V. and Nelson, R.J. 1996. WinBoot: a programme for performing bootstrap analysis of binary data to determine the confidence limits of UPGMA-based dendrograms. IRRI Disc. Ser. No. 14. International Rice Research Institute, Manila, Philippines.

\section{How to cite this article:}

Kuldeep Jangid, K. Ram Krishna, Naresh Parashar, Bhawana Bhatt, Arpit Gaur and Vinod Kumar. 2017. Assessment of Genetic Diversity for Storage Seed Protein in a Set of Released Varieties and their Diallel Set of Crosses in Indian Mustard [Brassica juncea (L.) Czern. \& Coss.] Using SDS PAGE. Int.J.Curr.Microbiol.App.Sci. 6(8): 2241-2248.

doi: https://doi.org/10.20546/ijcmas.2017.608.263 